\title{
A case of myocardial infarction following the use of clarithromycin
}

\author{
Klaritromisin kullanımına takiben gelişen \\ miyokard infarktüsü \\ *Tarık Kıvrak ${ }^{1}$, Hakkı Kaya ${ }^{2}$, Dursun Akaslan ${ }^{1}$ \\ ${ }^{1}$ Cardiology Clinic, Sivas State Hospital, Sivas, Turkey \\ ${ }^{2}$ Department of Cardiology, Cumhuriyet University School of Medicine, Sivas, Turkey \\ Corresponding author: Dr. Tarık Kıvrak, Kardiyoloji Kliniği, Sivas Devlet Hastanesi, TR-58100 Sivas, Türkiye \\ E-mail: tarikkivrak@gmail.com \\ Received/Accepted: December 27, 2015/June 09, 2015 \\ Conflict of interest: There is not a conflict of interest.
}

\section{SUMMARY}

Kounis syndrome is the consensus of acute coronary syndromes with conditions conjunction with cell activation(mast, eosinophil.) following an allergic pathology. Our case report a 65-year-old man who happened a ST-segment elevation myocardial infarction after used clarithromycin. Our patient did not occur signs of anaphylaxis or shock, however this situation occured three days after use. Patient's coronary angiography showed right coronary artery occluding the vessel partially,however it was completely patent ten days ago. We explicated our patient's situation as an impression of Kounis syndrome. To our knowledge, this is the first case of Kounis syndrome showing may caused by use clarithromycin.

Keywords: Kounis syndrome, myocardial infarction, thrombosis

ÖZET

Kounis sendromu hücresel aktivasyonu(mast, eozinofil) takiben gelișen akut koroner sendrom ile ilişkili allerjik patolojidir. Vakamız klaritromisin kullanımını takiben gelişen ST elevasyonlu miyokard infarktüsü olan 65 yaşında erkek hastadır. Hastada anaflaksi veya şok bulgusu yoktu, fakat bu durum kullanımdan 3 gün sonra geliști. Hastanın koroner anjiyografisinde sağ koroner arterde tıkanıklık saptandı, bununla birlikte on gün önce tamamen açık saptandı. Bu hastamızdaki durumu kounis sendromu olarak değerlendirdik. Literatürdeki klaritromisin kullanımına bağlı gelişen ilk vakadır.

Anahtar sözcükler: Kounis sendromu, miyokard infarktüsü, tromboz

\section{INTRODUCTION}

Kounis syndrome is the concurrence of acute coronary syndromes (ACS) with conditions associated with mast cell activation including allergic or hypersensitivity as well as anaphylactic or anaphylactoid reaction ${ }^{1-2}$. As far as we knew, kounis syndrome due to use of chlaritromycin has not yet been reported. We present here a rare case of acute myocardial infarction due to clarithromycin on day three after use. Because this syndrome usually happens within hours or even minutes.

\section{CASE REPORT}

A previously healthy 65-years-old male presented to the emergency department with typical chest pain that began 4 hours ago while he was using clarithromycin ever since three days. Immediate electrocardiogram revealed sinus rhythm with a heart rate of 58 beats per minute and normal axis however there were ST segment elevation on leads DII, DIII and aVF and DI and aVL with reciprocal ST segment depression. His physical examination was normal. Transthoracic echocardiography displayed inferior wall hypokinesis (EF: 40\%). Troponin- $\mathrm{T}$ level was $7.7 \mathrm{ug} / \mathrm{L}$ (normal range; $<0.01 \mathrm{ug} / \mathrm{L}$ ), white blood cell was $14.1 \times 10^{\wedge} 3 \mathrm{uL}$ (normal range; 3.510.5), basophile was $1.4 \times 10^{\wedge} 3 \mathrm{uL}$ (normal 
range; $0-1.0$ ) and eosinophile was $4.8 \times 10^{\wedge} 3$ uL (normal range; 0-0.5). $\mathrm{He}$ was transferred to cardiac catheterization laboratory which revealed thrombus in the right coronary artery (Figure 1). There was no any other coronary lesion, however, our patient's coronary angiography made ten days ago which was normal (Figure 2). We decided to administer percutan coronary intervention (PCI). After PCI, chest pain disappeared and electrocardiogram showed more than $70 \%$ of resolution of ST elevation. And our patient was discharged from the hospital after five days.

He was using clarithromycin $500 \mathrm{mg}$ daily for three days because of he had otitis media. There was no family history of cardiovascular disease or any other risk factor. Drug-induced coronary spasm was less likely by a negative urine toxicology screen. Tendency to thromboembolism including antiphospholipid syndrome, factor V Leiden mutation, proteins $\mathrm{C}$ and $\mathrm{S}$ deficiencies, connective tissue diseases were screened and excluded.

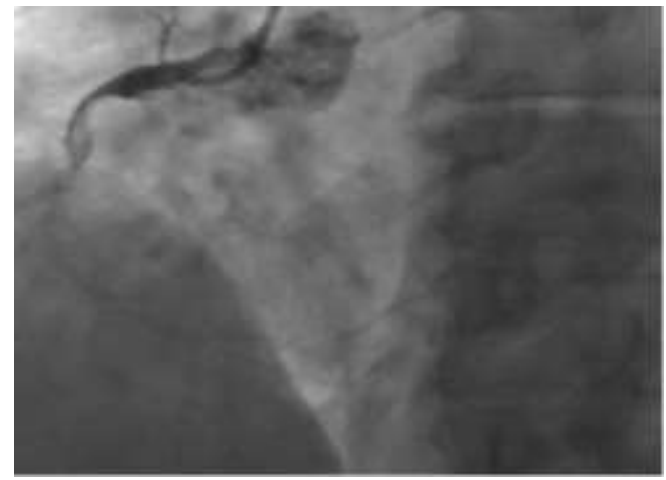

Figure 1: Image of right coronary artery.

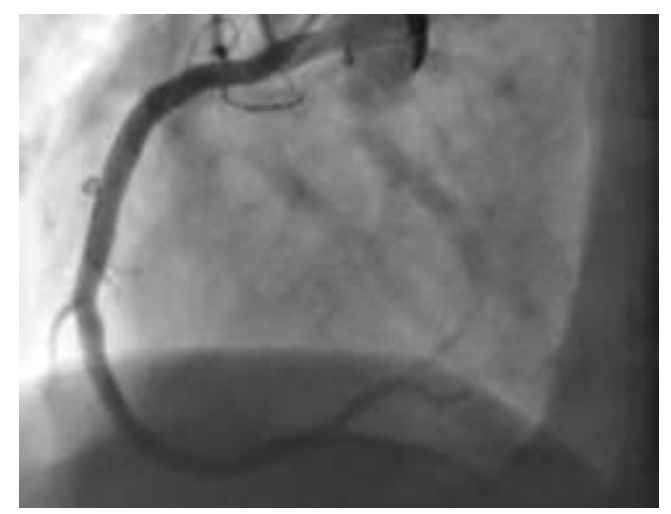

Figure 2: Image of right coronary $\operatorname{artery}(10$ days ago).

\section{DISCUSSION}

Myocardial infarction concomitance allergic reactions are identified in the literature as Kounis syndrome (KS) in $1991^{3}$. Many reasons can be KS. Allergens such as foods, insect venom, iodine contrast media or drugs induce mast cell degranulation, resulting in the release locally and into the systemic bloodstream of a number of vasoactive mediators (histamine, leukotrienes, serotonin) and proteases (tryptase, chymase) ${ }^{4}$. This mediators cause pathology. KS has been classified into two groups ${ }^{5}$ : Type I ; chest pain during an acute allergic reaction in patients without risk factors or coronary lesions, in which the allergic event induces coronary spasm that causes chest pain and electrocardiographic changes secondary to ischemia, while the cardiac enzymes may be either normal or reflect progression towards acute myocardial infarction. The explanation for this type would be endothelial dysfunction and/or microvascular angina. Type II (with coronary disease): Chest pain during an acute allergic reaction in patients with preexisting atheroma disease. Acute mediator release in such cases may induce atheroma plaque erosion or rupture, clinically resulting in acute myocardial infarction ${ }^{5}$. In recent years a third type has been proposed comprising patients with drugeluting stent thrombosis ${ }^{6}$. In the present case, it may be type I but as angiographic view may be type II .Because our patient had normal coronary before this event. Our case is important because of it occured three days after medication in that this pathology usually happens within minutes or hours.

Therefore our case is the first case in the literature. Secondly, it developed that due to clarithromycin use. It is the first case because of no cases associated with clarithromycin use in the literature. In conclusion, Kounis syndrome is an uncommon clinical entity, and its diagnosis is difficult. It is important for clinicians to keep this scenario in mind while treating an allergic reaction associated with acute chest pain. 


\section{REFERENCES}

1. Kounis NG. Kounis syndrome (allergic angina and allergic myocardial infarction): A natural paradigm? Int J Cardiol 2006; 110: $7-$ 14.

2. Biteker M. Current understanding of Kounis syndrome. Expert Rev Clin Immunol 2010; 6: 777-88.

3. Kounis NG, Zavras GM. Histamine-induced coronary artery spasm: the concept of allergic angina. Br J Clin Pract 1991; 45: 121-8.

4. Vivas D, Rubira JC, Ortiz AF, Macaya C. Coronary spasm and hypersensitivity to amoxicilin: Kounis or not Kounis syndrome? Int J Cardiol 2008; 128: 27981.

5. López PR, Peiris AN. Kounis syndrome. Sout Med J 2010; 103: 114855.

6. Kounis NG, Filippatos GS. Takotsubo and Kounis syndrome: is there any association? Circ J 2007; 71: 170. 